\title{
THE EFFECT OF JEMBER FASHION CARNAVAL AND SPONSORSHIP ON COMPANY IMAGE PT. MARTINA BERTO
}

\author{
Vegys Virgynitha Yussy Jessyca Gultom, Angela Clarissa, Marcha Chryztantya \\ STIKOM The London School Of Public Relations Jakarta \\ vegysg@gmail.com \\ Diajukan: 05-07-2019; Direview: 14-08-2019; Diterima: 23-12-2019;
}

\begin{abstract}
In 2015, Indonesia's GDP growth reached 852.24 trillion and fashion became an export commodity that dominated up to $56 \%$. This stimulates the emergence of various fashion shows in Indonesia, one of which is the Jember Fashion Carnaval event sponsored by PT. Martina Berto from 2003. This study aims to find out whether there is an international standard JFC event that can improve the company's image of PT. Martin Berto as a local cosmetics company with international standard. This study uses a quantitative methodology with an instrument test in the form of a questionnaire distributed online to 100 respondents. The results of the study show that JFC events and sponsorships contribute to the corporate image of PT. Martina Berto at 53.6\%. Separately, the event variable has an effect of 0.614 and the sponsorship variable has an effect of 0.326 on the corporate image of PT. Martina Berto. The results of this study can be used to increase the variable-forming elements that affect the company's image.
\end{abstract}

Keywords: event, sponsorship, corporate image

\section{INTRODUCTION}

$\mathrm{T}$ The fashion trend that is constantly changing rapidly has affected Indonesia's GDP growth in 2015 by $4.38 \%$ and contributed $7.38 \%$ to the total national economy through the creative economy sector. Export commodities from Indonesia's creative economy are dominated by fashion by $56 \%$, followed by $37 \%$ craft and $6 \%$ culinary (BEKRAF, 2017) this makes employment in Indonesia for the creative economy sector doubled compared to Latin America, this reason also that made the appearance of various fashion shows in Indonesia such as Indonesia Fashion Week, Jakarta Fashion Week to Jember Fashion Carnaval.

Jember was set to become a carnival city in Indonesia by Arief Yahya as Minister of Tourism because of its consistency in organizing fashion shows that raised the theme of Indonesian culture but managed to attract international attention, this did not escape the unique events of JFC, having the longest catwalk in the world $3.6 \mathrm{~km}$, empowering the surrounding community to make their own costumes to be exhibited, followed by more than 2,000 models and various achievements on the international stage. JFC also succeeded in increasing the regional economy from 2,5 billion to 8,5 billion in 2013 (Proborini, 2013, p.263). Until 2017, at least JFC has won 13 fashion contests, some of which are Carnaval de Victoria (Africa), Borobudur Chronicle (Florida), Wonderful of Betawi (Malaysia and Garuda in Diversity (in Miss Universe 2017). JFC also holds overseas events such as 2015 JFC are present in Singapore, in 2016 the JFC is back in events in Korea, India, Australia and 2017 in Hong Kong, Pakistan and Africa. (Jember Fashion Carnaval, 2017)

The success of an event is certainly supported by many things from the preparation of the committee to those who support the implementation of the event, in this study PT. Martina Berto as a local cosmetics company wants to enhance the image of a company that has international quality. It also supports the JFC event by performing a public relations role, namely becoming an official sponsorship. As a corporate communicator, one 
of the roles of a public relations officer is to improve the company's image using a variety of ways and channels, some of which utilize media relations, advertorials, social media, newsletters, brochures \& catalogues, business events, speaking engagement, partnership, employee relations and community relations (business.qld.gov.au, 2017).

This study aims to identify the efforts of PT. Martina Berto in improving the company's image as a local cosmetics company with international standards by sponsoring events that promote local culture and international standards. Then the purpose of this study was to determine the direction of influence and the magnitude of the X1 variable (JFC events) on the $\mathrm{Y}$ variable (company image of PT. Martina Berto), to determine the direction of influence and the magnitude of the X2 variable (sponsorship) on the $\mathrm{Y}$ variable (company image of PT. Martina Berto) and find out the most influential factors simultaneously on the $\mathrm{Y}$ variable (corporate image of PT. Martina Berto).

\section{LITERATURE AND RESEARCH METHODS}

In the preparation of the literature review, the author uses journal articles as a reference, research conducted by Grohs, Wegner and Vsetcka entitled Assesing the Effectiveness of Sport Sponsorship explains the forming elements of sponsorship variables that can influence brand recall. Another article used by the authors of Gayatri and Hutabarat entitled The Influence of Sponsors - a congruence event in sponsorship of music festivals, this article was also conducted to see the influence sponsorships give in an event on the image of the product and the brand of sponsors. If it is concluded from the research that has been done, there are influences given by events and sponsorships on image formation. Image is a concept of trust or ideas formed in the mind of the target audience of a product or company. More broadly, corporate image is a function of public relations. According to The Institute of PR "PR is the overall effort that is carried out in a planned and continuous manner in order to create and maintain good intentions and mutual understanding between an organization and all its people" (Nova, 2011, p.45). When associated with this research, PT. Martina Berto is working to improve the image of an international cosmetics company with international standards by running the PR function as the official sponsor for the JFC event. The PR function is certainly not free from the goals to be achieved, according to Ruslan, the main goal of a PR is (Nurjaman\&Umam, 2012, p.113): a) Growing a positive corporate image for the external public including within the community and customers.; b) Encouraging mutual understanding between the public target and the company.; c) Develop a synergy of marketing functions with PR.; d) Effective in building brand recognition and knowledge.; e) Supporting the marketing mix.

To achieve public relations goals, there are several strategies that can be done, starting from publication, holding or engaging in events (as an organizer or event supporter), publicity from the media, building good relations with audiences, and conducting CSR activities. Obtaining positive publicity from the media, as well as reciprocal communication that occurs during the event, shows good intentions or positive image of the company, and builds new connections with potential stakeholders. The things that must be considered in organizing an event are location, day, date and selection of the right time.

\section{Event}

According to Noor (Simanjuntak et al, 2018, p.146), the event has several characteristics because each event must have its own characteristics. Event can be defined as special activities that doesn't usually happen in other day (Rahayu, 2013. p.243) . However the characteristics of the event are almost the same as the services provided by other service industries. These characteristics are: a) Uniqeness, uniqueness can come from participating participants, the environment around the event, visitors to events and other things that make the event unique and different from before. The uniqueness of the JFC program is to make the city square of Jember as far as $3.6 \mathrm{~km}$ as a catwalk, and make the community as a model for fashion shows.; b) Perishability, every event that has been held must 
have differences and characteristics, perishability related to the use of facilities, and assessment of the success of publicity in disseminating information related to the event. JFC held from 2003 always presents a different theme, although it is always held in the town square of Jember, the diversity of events continues to increase in each year, and the selection of media for promotion is increasingly widespread using social media.; c) Intangibility, talking about the impression that the audience gets after watching an event. This is what the organizer needs to think about how to form impressions and convey the wishes to be conveyed to the public. At $\mathrm{JFC}$, the impression of Indonesian culture is very well displayed by the models who design their own clothing that is themed and named according to the regions in Indonesia.; d) Ambiance and service, organizing an event also needs to pay attention to the event seconds such as location, place to stay, how to get a ticket and others as it is. JFC events held in the town square make it easy for local and international tourists to attend because there are various lodging options that are not far from the location of the event.; e) Personal interaction, or relationships built by the organizers and supporters of the event to the audience present. In the JFC event, besides visitors can watch it directly, through a JFC personal account there is also an event for viewers outside Jember, in addition through the @ sariayu_mt account as a supporting party for the event, question and answer activities and quizzes are held to establish communication with the audience in Jember and those outside the area.

\section{Sponsorship}

Sponsorship is a product or financial support provided by individuals, organizations or companies and requires reciprocity in the form of positive conversation. According to Jefkins, there are 16 reasons why a company gives sponsorships, some of which are: a) obtaining international publications for a global market, b) improving corporate image by providing an image that the company is responsible for society, c) to show concern for the local group with sponsoring events in the region, d) building corporate identity by showing logos, colors, schemes, and corporate identity, e) to build media interest, and attract consumer awareness. The main reasons for sponsor providers are (Jefkins, 2004): To launch a campaign through publications, supporting marketing strategies or policies and showing good intentions of the organization or company to carry out its social responsibilities in the hope that the company will gain a good reputation.

According to Grohs, Wegner and Vsetecka, there are four elements of sponsorship, namely (2004, p.122) .: a) Brand prominence, the public is expected to have basic knowledge of the sponsor and its products, this needs to be done by the sponsoring company by showing the attributes of the company to increase the recall sponsor and the public's ability to associate the sponsor relationship. At the JFC event, the introduction of Sariayu as a sponsor product from PT. Martina Berto can be seen from the use of make up, as well as publicity material carried out by both parties and publicity from the media.; b) Event-sponsors are fit, on the basis of distinguishing between functional and related images. Functional compatibility can be specified as a match between the sponsor and the sponsored event. At the JFC event, this match can be found from the corporate identity of PT. Martina Berto who prioritizes Indonesian culture and seeks to introduce it to the international world, as well as what JFC has to offer, namely fashion shows with the concept of Indonesian culture that is able to attract international interest.; c) Event involvement, it is important for sponsor providers to build good interactions with the event and the audience present. Sariayu through its Instagram account (@sariayu_mt) often interacts with its followers thanks to JFC events.; d) Exposure, a standard for understanding cognitive learning is a message growing along with the addition of exposure. More and more media that convey messages related to sponsorship are comparable to the influence they get. In this study, news was not only carried out by JFC and Sariayu but also received publicity from local and international media, this could affect the image of organizers and supporters of the event. 


\section{Company Image}

Image is a concept, idea, trust that is owned by the public towards individuals, organizations or companies. According to Bill Canton "the image is the impression, feeling, public image of the company; the impression that was intentionally created from an object, person or organization" (Soemirat\&Ardianto, 2010, p.112). Company image is one type of image according to Jefkins (Rahayu, B. 2014. p.15); the image of an organization as a whole that is formed from the history of the company's performance, financial stability, product quality and other factors. In this study PT. Martina Berto seeks to build an image as a local cosmetics company with international standard, through its product export activities to Malaysia, Brunei, Singapore, Middle East and China and its involvement in JFC events that carry the concept of Indonesian culture but have an international level.

The process of image formation occurs in the part of human cognition, explained by John S. Nimpoeno (Aprinta, 2014. p.4), stimuli or stimuli provided are useful for activating body parts, in this study the stimulus provided is in the form of information that continues to be delivered to the public, slowly formed perceptions, namely the results of observations that occur in the public, then this information will be processed and formed in the cognition, namely aspects of knowledge that relate to beliefs, ideas and concepts. This aspect of cognition is what the company wants to use to convince the public that PT. Martina Berto is an international local cosmetic company. Furthermore, the company's image is formed from various elements.

According to Shirley Harrison (Ulum, Arifin \&Fanani. 2014. p.3) company image includes four elements, namely: a) Personality, the overall characteristics of the company that are understood by public targets such as companies that can be trusted, companies that have social responsibility. PT. Martina Berto builds the personality of the company through the operation of a world-class company that does not abandon Indonesian culture from the selection of names and colors that are in accordance with Indonesian culture.; b) Reputation, things that have been done by the company and are believed to be public targets based on the experience of themselves and others. PT. Martina Berto which was founded in 1977 is a company that has a good reputation, this is seen from its consistency to this day and various acknowledgments from inside and outside the country.; c) Value, is the values that have been done by the company and are believed to be public targets based on the experience of themselves and other parties. The involvement of PT. Martina Berto in the international arena shows the value of Indonesian culture that is loved by the international community if it is packaged well.; d) Corporate identity, a component that makes it easier for the public to target the company such as logos, colors and slogans. DR. H. C Martha Tilaar is a figure who has been known to the wider community as the founder of PT. Martina Berto and various products and services offered to the public.

It is important for a company to have a positive image because it will have an impact on competitiveness in the medium term, be a protector in times of crisis, become an attraction as well as differentiate from similar companies, increase marketing effectiveness and save operational costs. When linked in this study, the benefits of positive images obtained by PT. Martina Berto is of special interest because it is a sponsorship for events that are gaining worldwide attention.

\section{Research Hypothesis}

This study aims to test six hypotheses formed from the background. H01 = There is no change of X1 variable (JFC event) to variable Y (company image of PT. Martina Berto), Ha1 = There is the influence of X1 variable (JFC event) on variable Y (company image of PT. Martina Berto), H02 $=$ There is no effect of $\mathrm{X} 2$ variable (sponsorship) on variable Y (company image of PT. Martina Berto), Ha2 = There is influence of $\mathrm{X} 2$ variable (sponsorship) on variable Y (company image of PT. Martina Berto), $\mathrm{H} 03=$ There is no effect of $\mathrm{X} 1$ (JFC event) and X2 variables (sponsorship) simultaneously on variable Y (company image of 
PT. Martina Berto), Ha3 $=$ There are influences of variables X1 (JFC events) and X2 (sponsorship) simultaneously on variable Y (company image of PT. Martina Berto).

\section{Theoretical Framework}

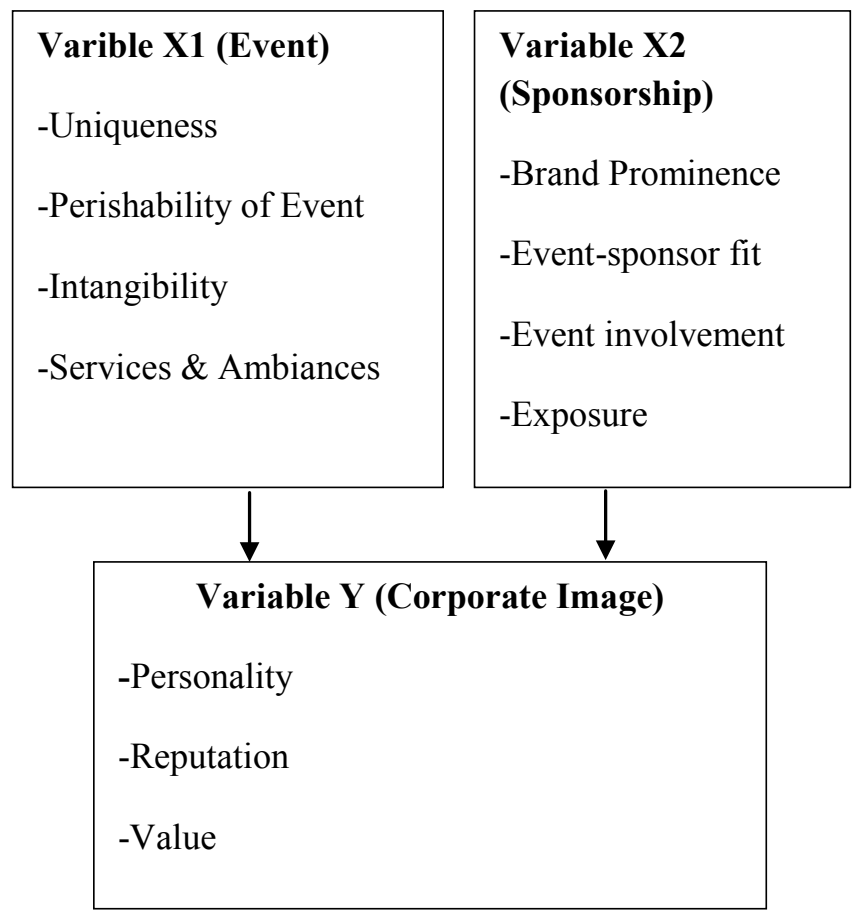

Source: researcher, 2018

In this research, positivistic paradigm is used, which can explain social science by combining deductive thinking with empirical observation. The approach used is quantitative, namely research whose results are in the form of numbers and using questionnaire as an instrument according to Kriyantono (Wijaya, 2013. p.6). Next the researchers used research instruments in the form of questionnaires distributed online to collect data that could explain the influence of free variables (event and sponsorship) with dependent variables (company goals ) The population of this study amounted to 350,000 people, this figurewas obtained from Marzuqi who had recorded the JFC audience in 2017 and in the publication at mediaindonesia. com. Continued Kriyantono "a sample must be able to represent the entire population researched, so that the sample can reflect all elements in the population proportionally or provide equal opportunities for all elements of the population to be chosen, so that it can represent the actual situation in the entire population". In determining the sample, researchers used the Yamane formula, because the population was scattered and not yet specific, it was found 100 respondents who would fill the questionnaire. The sampling technique used in this study was purposive sampling which, according to Notoatmodjo "as an example of sampling with certain considerations such as sifa and appropriate characteristics to be respondents with criteria that have been determined before" (2010, p.130). The next criteria formed was over 20 years old, had attended a JFC event and knew Sariayu was one of the products from PT. Martina Berto.

The primary data for this study originated from a questionnaire containing a number of researchrelated questions, as for secondary data collection, researchers obtained from publications carried out by JFC and Sariayu and publicity made by various local and international mass media.

\section{Characteristics of Respondents}

Of the 100 respondents, 57 people or $57 \%$ of respondents were female sex artists, with an age range of 19-23 years as many as 85 people or $85 \%$. The majority of respondents had the latest education as 76 students or $76 \%$ and 59 people or $59 \%$ of respondents had attended JFC events 1-2 times. As for respondents' knowledge of various products of PT. Martina Berto, 95 people knew about Sariayu products, 42 people knew about the product Mirabella, 37 people knew Rudy Hadisuwarno products, 25 people knew the PAC, 19 people knew BIOKOS, 17 people knew Caring Color and 17 others knew Cempaka, only 9 knew Belia products and 6 people who know Dewi Sri Spa products.

\section{Data Collection Instrument}

Before the questionnaire was distributed, the researcher conducted a pre-test to 30 respondents to test the feasibility of the questionnaire with two tests. According to Siregar (2014, p.337): a) Validity, an instrument is said to be valid if it has 
a product moment value $>0.3$. ; b) Reliability is an index that shows the extent to which a tool can be used to use more than twice to measure the same symptoms and have relatively consistent results. An instrument is said to be reliable if it has an alpha cornbach value $>0.6$.

\section{Data analysis technique}

The influence of JFC events and sponsorship of the corporate image of PT. Martina Berto will be tested using: a) The coefficient of determination ( $\mathrm{R}$ square) is a number that is used to determine the contribution or contribution given by an independent variable $(\mathrm{X})$ to the variable confiscated (Y). according to Siregar (2014, p.337), R square is calculated using the formula $=(\mathrm{r}) 2 \times 100 \%$; $\mathrm{b})$ Correlation test, used to measure the influence of variable $\mathrm{X}$ on the $\mathrm{Y}$ variable and the direction of the relationship (+) or (-).; c) Hypothesis testing, ANOVA table is a table used to see the extent of the influence of variable $\mathrm{X}$ on $\mathrm{Y}$ variables individually (Herjanto, 2007, p.104). If the number sig $>0.1$ then $\mathrm{HO}$ is accepted and if sig $<0.1$ then $\mathrm{HO}$ is rejected.; d) Multiple linear regression analysis, used to predict future data based on data that has been obtained before the previous. The equation used according to Siregar $(2013, \mathrm{p} .301)$ is $\mathrm{Y}=\mathrm{a}+$ $\mathrm{b} 1 \mathrm{X} 1+\mathrm{b} 2 \mathrm{X} 2$

\section{Variable Operationalization}

In this study, the Likert scale 1-5 was used to represent answers from respondents. In this study the X1 variable (JFC event) uses the concept of Any Noor: a) Uniqueness: Themes, locations and decorations are in accordance with the event held.; b) Persihability of event: the public gets information about the event through media publisher.; c) Intangibility: the community receives a good impression after attending the event.; d) Ambiance and service: People can enjoy the event atmosphere; e) Personal contact \& interaction: the community has contact with the organizing committee

For X2 variables (sponsorships) researchers use elements that are sparked by Grohs, Wegner and Vsetcka (2004): a) Brand prominence: the community knows the company after becoming a sponsor and the community does not know the company before becoming a sponsor.; b) Eventsponsor fit: the community assesses the suitability of the event with the sponsor.; c) Event involvement: the community attends an event because of the influence of the sponsor.; d) Exposure: people often get information about companies that sponsor in the mass media

For the $\mathrm{Y}$ variable (company image) the researcher uses the concept that was triggered by Shirley Horrison: a) Personality: PT. Martina Berto as an international standard local care and cosmetics product company; b) Reputation: PT. Martina Berto as a local international standard of care and cosmetics company that upholds Indonesia's cultural diversity.; c) Value: PT. Martina Berto as a local standard of care and cosmetics products company that has the values of discipline, honesty, faith and innoation as well as godliness and tenacity.; d) Corporate identity: PT. Martina Berto as a local standard of care and cosmetics products company that makes Martha Tilaar a company icon.

Researchers tend to make generalizations and lack of direct involvement by researchers because of the requirement to volunteer at JFC 2018 to obtain primary information.

Table 1.

Results of Validity and Reliability

\begin{tabular}{ccc}
\hline & Validity & Reliability \\
\hline Event JFC & 0,777 & 0,860 \\
\hline Sponsorship & 0,764 & 0,846 \\
\hline Citra perusahaan & 0,796 & 0,918 \\
\hline
\end{tabular}

Source: researcher, 2018 


\section{ANALYSIS AND DISCUSSION}

\section{Instrument Test Results}

The validity test performed on the questionnaire has $\mathrm{r}$ count $>0.3$ for $\mathrm{X} 1$ variable (JFC event), X2 variable (sponsorship) and $\mathrm{Y}$ variable (company image PT. Martina Berto) means, each question in the questionnaire is declared valid. Reliability test is also performed on $\mathrm{X} 1$ variable (JFC event), X2 variable (sponsorship) and $\mathrm{Y}$ variable (company image of PT. Martina Berto) which has a cornbach alpha value above 0.6 , meaning that each variable from the questionnaire is declared reliable (table $1)$.

Table 2.

Results of descriptive data analysis of variable X1 (JFC event)

\begin{tabular}{|c|c|}
\hline Element & Mean Interpretation \\
\hline Uniqueness & 35,6 Strongly agree \\
\hline Perishability of Event & Agree \\
\hline Intangibility \& Tangible & 40,3 Strongly agree \\
\hline Ambiance \& Service & Agree \\
\hline Personal Contact \& Interaction & Agree \\
\hline
\end{tabular}

Source: researcher, 2018

Based on table 2, it can be seen that the respondents strongly agree on the uniqueness element, namely JFC is unique in organizing the event. 35 respondents agreed with the perishability of event element, which meant that the JFC event coverage in the mass media had sufficient needs, besides the respondents strongly agreed on the intangibility and tangible elements, namely the success of the event formed a good feeling in the minds of respondents. Respondents also agreed that the ambiance and service element offered by JFC was able to make respondents enjoy the event, finally the personal contact and interaction elements were also agreed by respondents that there was communication built by the organizers and supporters of the method.

Based on table 3, respondents agree on the elements of brand prominence or knowledge of respondents to the company before and after the JFC event, respondents also strongly agree that there is a match or event-sponsor fit to the sponsors conducted by PT. Martina Berto for the JFC event. But respondents felt doubtful that their presence at JFC was due to the influence of sponsorship. In addition, the community feels agreed on the element of exposure, which is why the community has easily been informed about JFC events and companies that support the running of the event.

Table 3.

Results of descriptive X2 variable (sponsorship) data analysis

\begin{tabular}{ccc}
\hline Element & \multicolumn{2}{c}{ Mean } \\
\hline Brand Prominence & 30,5 & Agree \\
\hline Event-sponsor fit & 38 & Strongly agree \\
\hline Event involvement & 38 & Doubtful \\
\hline Exposure & 33,5 & Agree \\
\hline \multicolumn{3}{c}{ Source: researcher, 2018}
\end{tabular}

Table 4.

Results of descriptive data analysis of variable $Y$ (company image of PT. Martina Berto)

\begin{tabular}{ccc}
\hline Element & \multicolumn{2}{c}{ Mean } \\
\hline Personality & 39 & Agree \\
\hline Reputation & 39,6 & Agree \\
\hline Value & 43 & Strongly agree \\
\hline Corporate Identity & 37 & Strongly agree \\
\hline \multicolumn{2}{c}{ Source: researcher, 2018 }
\end{tabular}

Based on table 4, respondents agree with the personality elements that PT. Martina Berto is an international standard of care and cosmetics products company. Respondents also agreed with the reputation of PT. Martina Berto, which has international standard care and cosmetics products that uphold Indonesian cultural diversity. In addition, respondents strongly agree with the value of the company, namely promoting discipline, honesty and innovation. Finally, respondents strongly agree to corporate identity elements, namely the introduction of Martha Tilaar's figure behind the company's name. 
Table 5.

Determination Coefficient Test Results

\begin{tabular}{ccccc}
\hline Model & R & R Square & Adjusted R Square & Std. Error of the Estimate \\
\hline 1 & $.739^{\mathrm{a}}$ & .546 & .536 & .51533 \\
\hline \multicolumn{4}{c}{ Source: researcher, 2018}
\end{tabular}

Based on table 5, the value of the correlation $(R)$ is 0.739 which means the level of the relationship is strong. Thus it can be concluded that there is a strong relationship between JFC events and sponsorship of the corporate image of PT. Martina Berto, in a positive direction. Furthermore, the adjusted $\mathrm{r}$ square value is 0.536 , which means that $53.6 \%$ of the company's image that occurs at PT. Martina Berto is influenced by JFC event variables and sponsorships, while at least $45.4 \%$ are influenced by facts outside of research.

Table 6.

Hypothesis Test Results F

\begin{tabular}{|c|c|c|c|c|c|c|}
\hline & Model & Sum of Squares & df & Mean Square & $\mathrm{F}$ & Sig. \\
\hline \multirow[t]{3}{*}{1} & Regression & 30.961 & 2 & 15.480 & 58.292 & $.000^{\mathrm{b}}$ \\
\hline & Residual & 25.760 & 97 & .266 & & \\
\hline & Total & 56.721 & 99 & & & \\
\hline
\end{tabular}

Source: researcher, 2018

Based on table 6, the significance value is at is a significant influence from JFC events and 0.0, which means that $\mathrm{H} 03$ is rejected and Ha3 simultaneous sponsorship of the corporate image is accepted. So it can be concluded that there of PT. Martina Berto.

Table 7.

t Hypothesis Test Results

\begin{tabular}{|c|c|c|c|c|c|c|}
\hline & \multirow[t]{2}{*}{ Model } & \multicolumn{2}{|c|}{ Unstandardized Coefficients } & \multirow{2}{*}{$\begin{array}{c}\text { Standarized Coefficients } \\
\text { Beta } \\
\end{array}$} & \multirow[t]{2}{*}{$\mathrm{t}$} & \multirow[t]{2}{*}{ Sig } \\
\hline & & $\mathrm{B}$ & Std. Error & & & \\
\hline \multirow[t]{3}{*}{1} & (Constant) & .422 & .371 & & 1.138 & .258 \\
\hline & $\mathrm{X} 1$ Event & .614 & .122 & .457 & 5.036 & .000 \\
\hline & X2Sponsor & .326 & .084 & .353 & 3.892 & .000 \\
\hline
\end{tabular}

Source: researcher, 2018

Significance value $<0.05$ on the $\mathrm{X} 1$ variable (JFC event) states that Hol is rejected and Hal is accepted, meaning that there is the influence of the JFC event on the corporate image of PT. Martina Berto. Significance value $<0.05$ on $\mathrm{X} 2$ variable (sponsorship) states $\mathrm{Ho} 2$ and $\mathrm{Ha} 2$ accepted means that there is influence of sponsorship on the corporate image of PT. martinaberto. From the above research it was concluded that the $\mathrm{X} 1$ variable (JFC event) became the dominant factor that influenced the company image of PT. martinaBerto and obtained multiple linear regression equation as follows:

$$
Y=0,422+0,624 X 1+0,326 \times 2 \text {. }
$$

It can be concluded that partially $\mathrm{X} 1$ variable (JFC event) and X2 variable (sponsorship) are 
affected by variable $\mathrm{Y}$ (corporate image of Pt. Martina Berto) which if the value of JFC event rises by one unit, the company image of PT. Martina Berto will increase by 0.614 assuming other variables are constant. If the value of sponsorship goes up one unit then the company image of PT Martina Berto will increase by 0.326 assuming other variables are constant. It can also be concluded that the X1 variable (JFC event) has a dominant influence on the corporate image of 0.614 and the sponsor variable influences the company image by 0,326 .

Based on the research that has been done, it can be concluded from 100 respondents distributed online the majority of respondents were female $(57 \%)$, aged $19-23$ years $(85 \%)$, the last education was students $(76 \%)$ and had been present at the event JFC 1-2 times as much (59\%). Of the 100 respondents, it was known that the product most known to the respondents was Sariayu (95\%).

\section{CONCLUSION}

The conclusion from the research of The Effect of Event JFC and Sponsorship toward corporate image of Pt. Martina Berto is answering the initial purpose of the research, it is proven that there is an influence given from the JFC event to the company image of 0.614 , while the influence given by the sponsor element to the company image is 0.326 . Simultaneously elements of the JFC event and sponsorship can explain the corporate image of Pt. Martina Berto of 53.6.

This shows that by being involved in the JFC event and conducting sponsorship, it is proven that it can affect the corporate image of Pt. Martina Berto, another interesting thing is the event element that gets higher value than the sponsor element, as well as being the dominant element in influencing the company's image.

The reason why the JFC event element can be the dominant element is because the majority of respondents answered strongly agree and agree when asked whether Pt. Martina Berto is a suitable company to sponsor a JFC event, besides that the majority of respondents also agreed to agree with the statement that by attending the JFC event they learned that Pt. Martina Berto is a company that sponsors the event through Sariayu products, the community also agrees that they get enough information about the product and the company from a variety of promotional materials this will have a good impact on the elements of corporate identity when the respondent is able to identify the company based on its attributes, in this study as many as 30 respondents claimed to be able to remember the company slogan and the figure Martha Tilaar was successfully identified as part of Pt. Martina Berto due to her involvement in the JFC event, besides being part of the JFC event directly affected the value of the company's personality because the majority of respondents strongly agreed I was asked whether Pt. Martina Berto is a cosmetics company that upholds the diversity of Indonesian culture. The company's involvement in the JFC event also had an impact on the value element of the company's image, the majority of respondents as many as 43 strongly agreed if $\mathrm{Pt}$. Martina Berto holds fast the pillars of Indonesian culture, which can be seen from her support in the JFC event.

\section{SUGGESTION}

The results of the study stated that the JFC event and sponsorship had a positive effect on the formation of the company's image. Thus it is expected that in the future PT. Martina Berto not only supports JFC events but also contributes to events that promote local culture and international standards, because event variables can significantly influence the image company PT. Martina Berto as a local international cosmetics company. Second, to maximize the company's image, there needs to be an increase in the exposure element, by publicizing Sariayu's involvement in the JFC event using publication material in the form of banners, flyers or on socialmedia@sariayu_mt. Third, It is expected that the future costs incurred by PT. Martina Berto to become a sponsor can be distributed to create her own event with the theme of culture, this is to give a better corporate image impact. And the last PT. Martina Berto needs to communicate more 
slogans the company and introduced to the public that Martha Tilaar is not only a brand but also the figure behind Martha Tilaar Group can go through events or gatherings with the media to get publicity. Because of 37 respondents were skeptical of the corporate identity of PT. Martina Berto.

\section{REFERENCES}

Ardianto, E., \& Soemirat, S. (2010). DasarDasar Public Relations. Jakarta: Remaja Rosdakarya.

BEKRAF. (2017). Data Statistik dan Hasil Survei Ekonomi Kreatif. Jakarta.

Aprinta, G. (2014). Strategi Cyber Public Relations Dalam Pembentukan Citra Institusi Pendidikan Tinggi Swasta. Jurnal The Messenger, 6(1), 1-7.

Grohs, R. Wagner, U. Vsetecka, S. (2004). Assesing The Effectiveness of Sport Sponsorships An Empirical Examination. Schmalenbach Business Review, 5(2), 119-138.

Ulum B, Arifin Z, Fanani D. (2014). Pengaruh Corporate Social Responsbility Terhadap Citra: Survei pada Warga Sekitar PT. Sasa Inti Gending-Probolinggo. Jurnal Administasi Bisnis, 8(1), 1-8.

Rahayu, B. (2014). Pengaruh Kualitas Pelayanan, Hubungan Pelanggan dan Citra Perusahaan Terhadap Loyalitas Melalui Kepuasan Nasabah. Jurnal Advance Vol 1, No. 2

Wijaya T C A. (2013). Motif Masyarakat Surabaya Dalam Menggunakan Iphone. Jurnal E-Komunikasi, 1(1), 1-10.

Marzuqi, Abdillah M. (2017, Agustus 13). Menerjemahkan Budaya dalam Kostum JFC. Diperoleh dari $m$ e d i a indonesia.com: http://mediaindonesia. com/

Mulyana, D. (2000). Ilmu Komunikasi: Suatu Pengantar. Bandung: Remaja Rosdakarya

Simanjuntak D F, Fauzi A, Irawan A. (2018). Pengaruh Event Pariwisata Terhadap Keputusan Berkunjung. Jurnal Administrasi Bisnis, 61(3), 144-153.

Notoatmojo. (2010). Metodologi Penelitian Kesehatan. Jakarta: Rineka Cipta.

Nova, F. (2011). Crisis Public Relations : Strategi PR Menghadapi Krisis, Mengelola Isu, Membangun Citra dan Reputasi Perusahaan. Jakarta: Rajawali Pers.

Nurjaman, K., \& Umam, K. (2012). Komunikasi \& Public Relation : Panduan Untuk Mahasiswa, Birokrat dan Praktisi Bisnis. Jakarta: Pustaka Setia.

Public Relations tools and activities. (n.d). Diperoleh dari business queensland: https://www.business.qld.gov.au/runningbusiness/marketing-sales/marketingpromotion/pr/tools-activities

Proborini CA. (2017). Jember Fashion Carnaval Dalam (JFC) Industri Pariwisata Di Kabupaten Jember. Mudra: Jurnal Seni Budaya, 32(2), 262-274.

Rahayu S. (2013). Pengaruh Event ESMOD Fashion Festival 2012 Terhadap Citra ESMOD Jakarta. Wacana Jurnal Ilmiah Ilmu Komunikasi, 12(3), 241-260.

Siregar, S. (2013). Metode Penelitian Kuantitatif: Dilengkapi dengan Perbandingan Perhitungan Manual \& SPSS. Prenada Media Group.

http://www.jemberfashioncarnaval.com/main.php, 